\title{
Perineuronal Satellite Cell
}

National Cancer Institute

\section{Source}

National Cancer Institute. Perineuronal Satellite Cell. NCI Thesaurus. Code C12619.

A flattened non-neuronal cell surrounding a gang lion cell. 